\title{
Effect of haruan (channa striata) extract on fibroblast cells count in wound healing
}

\author{
Ardi Siswanto, ${ }^{1 *}$ Nurdiana Dewi, ${ }^{2}$ Lisda Hayatie ${ }^{3}$
}

\section{Abstract}

Objective: The study aims to assess the mechanisms of wound healing in the buccal mucosa of wistar rats after administration of haruan extract by calculating and comparing the number of fibroblast cells. Material and Methods: Haruan extract has substantial properties such as albumin, zinc, copper and iron to accelerate wound healing. Haruan is Kalimantan's indigenous fish which has the potency to accelerate wound healing. Samples consisted of 4 treatment groups, $25 \%, 50 \%, 100 \%$ haruan extract treatment groups and negative control treated with aquadest for 7 days.

Keywords: Haruan extract, Wound healing, Fibroblast cell, Histopathology

Cite this Article: Siswanto A, Dewi N, Hayatie L. 2016. Effect of haruan (channa striata) extract on fibroblast cells count in wound healing. Journal of Dentomaxillofacial Science 1(2): 82-87. D0l:10.15562/jdmfs.v1i2.3

\begin{abstract}
'University of Lambung Indonesia

${ }^{2}$ Department of Oral Biology, Faculty of Dentistry, University of Lambung Mangkurat, Banjarmasin, Indonesia ${ }^{3}$ Department of Parasitology, Faculty of Medicine, University of Lambung Mangkurat, Banjarmasin, Indonesia
\end{abstract}

"Correspondence to: Ardi Siswanto, University of Lambung Mangkurat, Banjarmasin, Indonesia ardiboz@gmail.com

Received: 16 March 2016 Revised: 15 August 2016 Accepted: 17 August 2016 Available Online: 31 August 2016

\section{Introduction}

The oral cavity as an integral part of the body is often traumatized when performing its functions. Trauma can occur intentionally or not, which in turn will cause sores on oral mucous. ${ }^{1}$ Wound is a change in cellular network continuity and anatomy that can occur on the skin or mucosa and respond to the wound healing process. The process of wound healing is basically a complex cellular and vascular process and the focus was on restoring the integrity of the structure and function of damaged tissue. Wound healing generally consists of three phases, namely the inflammatory phase, the proliferative phase and remodeling phase. ${ }^{2}$

Inflammatory phase begins several minutes after the injury and lasts for about 3 days. ${ }^{3}$ Destruction, dissolution and the destruction of cells or agents causing cell damage occur in the inflammatory process. Macrophages appear in the first 48-96 hours after injury, then t-lymphocytes appear on fifth day and reaches the peak on the seventh day. Granulation tissue formation occur in the proliferative phase. This phase is also called fibroplasia phase, because it stands out of the proliferation of fibroblasts. Proliferative phase lasts until the end of the inflammatory phase until approximately the end of the third week which is characterized by deposition of extracellular matrix, angiogenesis and epithelialization. Remodeling phase is the final phase of the process of wound healing in soft tissue and sometimes called maturation phase of wound.
Results: Mean of fibroblast cells count reached its peak on day 7. Mean of fibroblast cells count in each group was 26.995, 40.500, 49.165, 24.495 respectively. Two way ANOVA and Post Hoc Least Significant Difference tests indicated there was a significant difference $(p<0.05)$ between haruan extract treatment group and negative control.

Conclusion: Haruan extract treatment significantly increases fibroblast cells count in wound healing process.

CrossMark 
endurance, increase levels of albumin and hemoglobin, eliminate oedema, speeding up the healing process of diseases such as cancer, TBC, hepatitis, diabetes, HIV, pre-eclampsia, nephrotic syndrome and additional nutrition for the elderly, pregnant women and children. ${ }^{8}$

Previously several previous studies indicated that haruan fish is one type of fish that have a fairly high content of albumin. Albumin is indispensable for the human body every day, especially in the process of wound healing. ${ }^{8,9}$ Other studies on the content of haruan extract by Santoso et al..$^{10}$ stated that haruan extract also contains compounds essential for the human body including zinc $(\mathrm{Zn})$, copper $(\mathrm{Cu})$ and iron $(\mathrm{Fe})$, which plays a role in wound healing.

The study aims to assess the mechanisms of wound healing in the buccal mucosa of wistar rats after administration of haruan extract by calculating and comparing the number of fibroblast cells.

\section{Material and Methods}

The design of the research was posttest-only with control group design and with a completely randomized design. The sampling technique of wistar rats was done by simple random sampling based on the calculation formula from Federer. Extraction was conducted at the Faculty of Mathematic and Natural Sciences University of Lambung Mangkurat, Banjarbaru, Indonesia and treatment in animals as well as making histology slides was done at the Veterinary Institute Banjarbaru. This research was approved by Medical Research Ethics Committee Lambung Mangkurat University, Banjarmasin.

The materials used were haruan fish, aquadest, diethyl ether for anesthesia inhalation and materials for making histology slides. The tools used were steam pan, cookers, vacuum rotary evaporator, Erlenmeyer flask with tube, scalpel, blade, syringe injection, half-moon excavator and tools for making histology slides. To obtain 100\% haruan extract the haruan fish was steamed with aquadest in the ration $1: 1$ with a temperature $70^{\circ} \mathrm{C}$ for 50 minutes then concentrated using a vacuum rotary evaporator for 5 hours.

Twenty four male wistar rats, weight $200-250$ g, aged 2-2.5 months and in healthy condition were divided into twelve groups of rats consisting of four treatments, namely aquadest, $25 \%$ haruan extract, 50\% haruan extract and 100\% haruan extract. Inhalation anesthetic was done, then cuts were made over $1 \mathrm{~cm}$ long and $1 \mathrm{~mm}$ deep by using a sterile scalpel and blade. Provision of intra-oral drug was done by half-moon excavator once every
24 hours. Haruan extract dosage was $10 \mathrm{ml} / \mathrm{g}$ BW then do decapitation on the 3rd, 5th and 7th days.

Buccal mucosa tissue were taken and fixed in $10 \%$ neutral buffered formalin for 24 hours, then tissue processing and cultivation were sone in paraffin blocks. Paraffin blocks were cuts with a thickness of $5 \mu \mathrm{m}$ and placed on an object glass. Deparaffinization and dehydration was done on the tissue that was on a glass object, then stained with hematoxylin eosin (HE).

Fibroblasts were observed with 400x magnification microscope at 3 fields. Data obtained by Shapiro Wilk normality test and homogeneity was obtained by the Levene's test, then analyzed using two-way ANOVA test and continued with LSD post hoc test. A value of $\mathrm{p}<0.05$ was considered statistically significant.

\section{Results}

Microscopic slides observations for counting the numbers of fibroblasts were performed at $400 \mathrm{x}$ magnification. The mean of fibroblasts in the group of aquadest, $25 \%, 50 \%$ and $100 \%$ haruan extract can be seen in figure 1 .

Based on figure 2, in general the mean of fibroblast cells all treatment groups on the 3rd, 5th and 7th days, are higher than the control group. The increase in the mean of fibroblasts occurred in all groups at each day of observation. In the treatment group the $25 \%$ haruan extract was marked with blue in diagrams, observations on 3rd day showed the mean of fibroblast cells were as much as

22.330 , the number increased on 5th day as much as 25.830 and the highest number on the 7 th day as much as 26.995 . In the group with $50 \%$ haruan extract the mean of fibroblasts on 3rd day was as much as 27 , then increased to 36.165 on 5 th day and on the 7th day as much as 40.5 . The mean of fibroblasts in $100 \%$ haruan extract group on the 3rd day was as much as 34.33 , on the 5th day increased to 36.66 and 49.165 on the 7th day. The control group marked with purple diagram shown that the observation on the 3rd day the mean of fibroblast cell is the smallest with a value of 20.495. On the 5th day and 7th day the mean of fibroblasts on the control group is also smaller than treatment group with the value of 22.165 on the 5th day and 24.495 on the 7 th day.

After the tabulation process was completed, the Shapiro-Wilk normality test was conducted. Based on normality test, it was showen that the data were normally distributed with significance value of $\mathrm{p}>0.05$. Furthermore, the homogeneity test data using Levene's test was conducted. Based on the test 


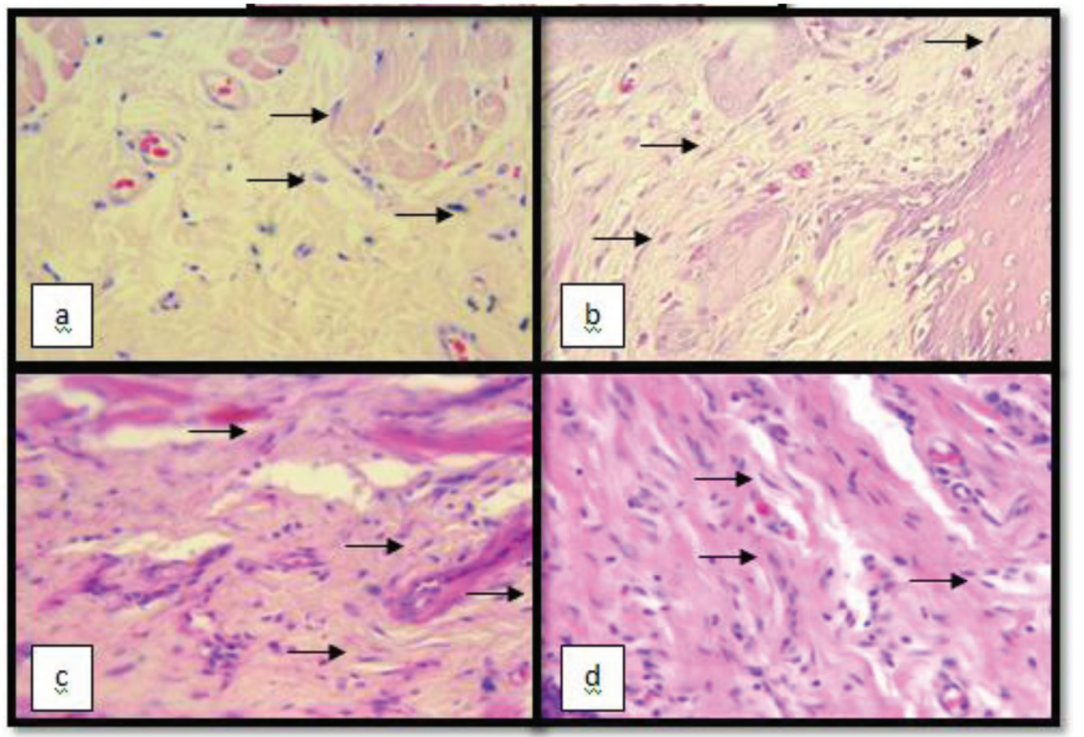

Figure 1 Histological view of fibroblast cells on buccal mucosa of rat tissue on the 7 th day. Aquadest A. $25 \%$ haruan extract B. $50 \%$ haruan extract C. $100 \%$ haruan extract and D. Fibroblast cells are pointed by arrows. HE stain, original magnification $\mathrm{x} 400$

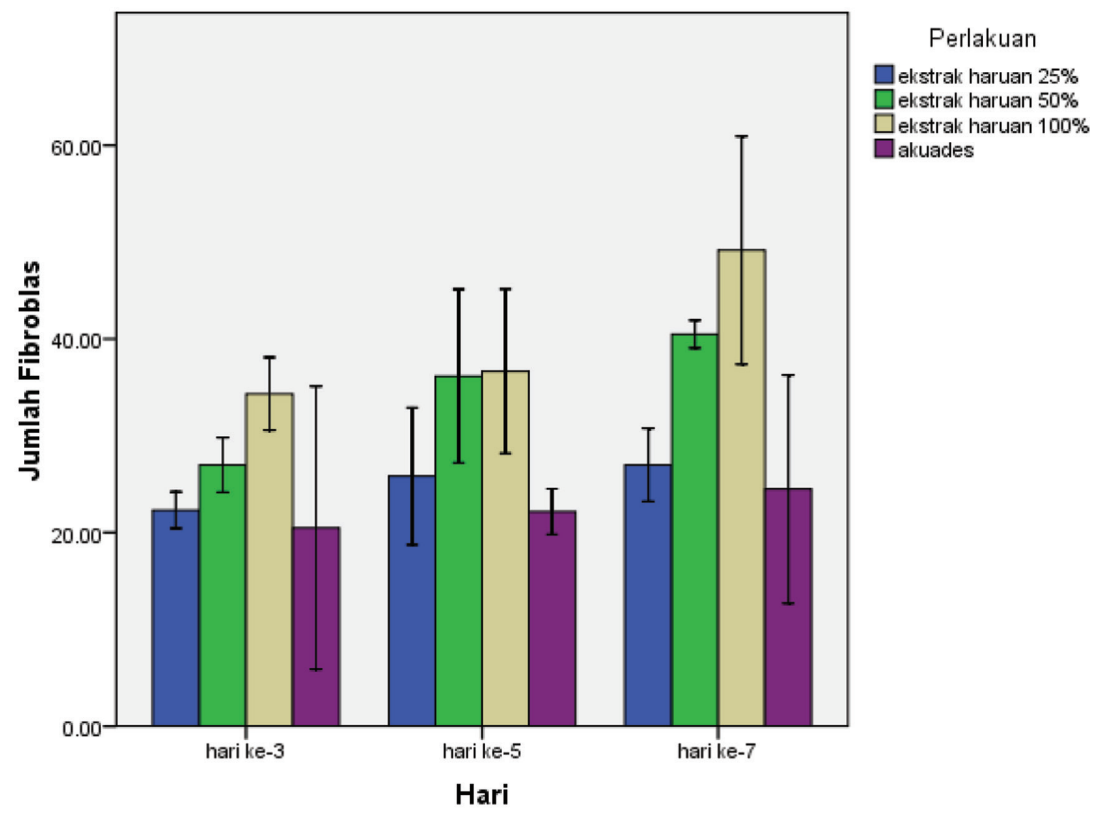

Figure 2 The comparison of mean of fibroblast cells among treatment groups

on treatment group and control group had a homogeneous variance with $\mathrm{p}>0.05$.

Based on the results of normality and homogeneity test, the research data had a value that is normal and homogeneous followed by two-way ANOVA test. Two-way ANOVA test was used to determine whether there were differences in the number of fibroblasts among each treatment group, among observation day as well as differences among treatments in each days.

The results of the data analysis by two-way ANOVA showed that the difference in the number of fibroblasts among the treatments have a significance value of $0.000(\mathrm{p}<0.05)$, which means that the fibroblasts number in the treatment $25 \%$, $50 \%, 100 \%$ haruan extract and aquadest showed significant differences. Differences in the number of fibroblasts by the observation days showed no significant differences with a significance value of $0.002(p<0.05)$, which means that there were significant differences in the $3 \mathrm{rd}$, 5 th and 7 th days. While the interpretation of interaction of two factors: the treatment and the observations days obtained significance value of 0.252 , which means there was no interaction between the treatments with the observations day.

The next test was Post Hoc LSD to determine observation days and treatment groups which showed significant differences. Based on the Post Hoc LSD test results, it can be seen that there was no significant difference in the mean of fibroblasts between 3rd and 5th days, with $\mathrm{p}=0.120(\mathrm{p}>0.05)$. Significant differences exist between the number of fibroblasts from 3rd to 7 th days with a value of $\mathrm{p}=0.001$ and between 5 th and 7 th days with a value of $\mathrm{p}=0.024$ because the significance value of $\mathrm{p}<0.05$. The number of fibroblasts based on days always increase, from 3rd day the number increased until 5th day and reached the peak at 7th day.

Post Hoc LSD test on the 3rd day showed that there were significant differences between 100\% haruan extract and aquadest with significance value of $0.023(\mathrm{p}<0.05), 100 \%$ haruan extract and $25 \%$ haruan extract with significance value of 0.036 $(p<0.05)$. Results on the 5th day showed significant differences between 25\% haruan extract and aquadest with significance value of $0.018(p<0.05)$, $50 \%$ haruan extract and $25 \%$ haruan extract with a significance value of $0.046(\mathrm{p}<0.05), 100 \%$ haruan extract and aquadest significance value of 0.016 $(\mathrm{p}<0.05), 100 \%$ haruan extract renewal and 25\% haruan extract with significance value of 0.040 $(\mathrm{p}<0.05)$. On the 7 th day the results showed that there were significant differences between 50\% haruan extract and aquadest with a significance value of $0.020(\mathrm{p}<0.05), 50 \%$ haruan extract and $25 \%$ haruan extract with a significance value of $0.034(\mathrm{p}<0.05), 100 \%$ haruan extract and aquadest with a significance value of $0.005(\mathrm{p}<0.05), 100 \%$ haruan extract and $25 \%$ haruan extract with a significance value of $0.007(\mathrm{p}<0.05)$.

Based on Post Hoc LSD test between the treatment groups it was noticed that there were significant differences between these groups. 50\% haruan extract and aquadest with a significance value of $0.000(\mathrm{p}<0.05), 50 \%$ haruan extract and $25 \%$ haruan extract with significance of value 0.001 $(\mathrm{p}<0.05) .100 \%$ haruan extract and aquadest with significance value of $0.000(\mathrm{p}<0.05), 100 \%$ haruan 
extract and 25\% haruan extract with significance value of $0.000(p<0.05), 100 \%$ haruan extract and $50 \%$ haruan extract with significance value of $0.032(\mathrm{p}<0.05)$. Between 25\% haruan extract and aquadest had significance value of 0.262 ( $p>0.05)$, which mean that there was no significant difference between the two treatments.

\section{Discussion}

The numbers of fibroblasts that increased indicates the level of the cell density also increases to form a new tissue so that rapid wound healing reached..$^{10}$ On the 3rd day of observation both the control group and the treatment group, have showed the presence of fibroblasts. Starting from the observation on the 3rd day, the mean of fibroblasts continued to increase until it reaches the mean of the highest on the 7th day. This is in accordance with the theory that during fibroplasia in the wound healing on 3rd day the number of young fibroblasts localized to the area of injury.

After cells suffered injury, the cells will repair through the healing process. One element that plays an important role in the healing process is fibroblasts. Fibroblasts have very big role on tissue repair process that is responsible for the preparation of protein structures product that will be used during the process of tissue reconstruction. ${ }^{11}$

Increase in the number of fibroblasts occurs during every treatment day, is thought to be an indicator of the wound healing process. The number of fibroblasts that increased indicates the level of the cell density that also increases to form a new tissue so that rapid wound healing reached. ${ }^{10}$ On the 3 rd day the mean of fibroblasts was fewest, this may occur because the fibroblasts appeared early in the proliferative phase i.e., between days 2 and 3. Shortly after the injury in wistar rat's buccal mucosa, a process of healing begins with the formation of blood clots on the wound surface. ${ }^{2}$ After that, there was an inflammatory reaction in the wound edge which indicates the inflammatory phase begins. Next will be the formation of granulation tissue in wounds. Histologically, granulation tissue is characterized by proliferation of fibroblasts and new capillaries are smooth and thinwalled. During the process of wound healing, fibroblasts will be active from the tissue surrounding the wound into the wound area and then will develop (proliferation) and releaseseveral substances (collagen, elastin, hyaluronic acid, fibronectin and proteoglycans) that play a role in the natural wound healing fibroblasts stimulated by interleukin-1 $\beta$ (IL-1 $\beta$ ), platelet derived growth factor (PDGF) and fibroblast growth factor (FGF). ${ }^{4}$ In addition there are transforming growth factor $-\beta$ (TGF- $\beta$ ), which stimulates the migration of fibroblasts in the area of injury.

Fibroblasts have a very important role in the proliferative phase. Fibroblasts produce collagen, glycosaminoglycans, elastin fibers and glyco-proteins that form the extracellular matrix that will fill the wound cavity and provides a foundation for keratinocyte migration. Fibroblasts digest fibrin matrix and replace it with the glycosaminoglycan with the help of matrix metalloproteinase (MMP). Extracellular matrix will be replaced by type III collagen which is also produced by fibroblasts with the passage of time. Furthermore, type III collagen is replaced by type I collagen in maturation phase. ${ }^{9}$ Interesting thing about this proliferative phase is that at a certain point, the whole process that has been described above must be stopped. Fibroblasts will soon disappear as soon as the collagen matrix fills the wound cavity and the formation of neovascular will decrease through the process of apoptosis. Regulatory failures at this stage, which until now was considered as the cause of fibrotic disorders such as hypertrophic scarring. ${ }^{13}$

This study result showed that haruan extract group had a significant influence on the number of fibroblasts compared to the negative control group that were given aquadest. Differences in the mean of fibroblasts is likely caused by important contents in haruan extract. Some compounds from haruan extract such as albumin, iron, zinc and copper allegedly could help in the speedup of wound healing process. ${ }^{5}$ Preliminary research that has been done on the haruan extract at a temperature of $90^{\circ} \mathrm{C}$ for 50 minutes and rotary showed the content of albumin (35.492 mg/L), Zn (5.75 mg/L), Cu (589 $\mathrm{mg} / \mathrm{L})$ and $\mathrm{Fe}(1.335 \mathrm{mg} / \mathrm{L})$ at 5 hours long rotary. Results obtained on a hours long rotary, albumin (34.146 mg/L), Zn (6.28 mg/L), Cu (0.953 mg/L) and $\mathrm{Fe}(0.990 \mathrm{mg} / \mathrm{L})$.

The increase in the number of fibroblasts was apparently due to the effect of existing content in haruan extract. A result study by Restiana et al. ${ }^{9}$ showed that haruan extract is one type of fish that contain high albumin content. The albumin is indispensable of human body every day, especially in the process of wound healing. Other studies on the content of haruan extract by Santoso et al. ${ }^{10}$ stated that haruan extract contains essential compounds for the synthesis of tissue and the wound healing process. Haruan extract contains substances that are necessary in the process of wound healing such as albumin, $\mathrm{Zn}, \mathrm{Cu}$ and $\mathrm{Fe}$. Albumin is one type of 
protein that plays a role in increasing the proliferation of fibroblasts thus increasing the synthesis, accumulation, and collagen remodeling. Zinc play a role in the growth and replication of cells (including fibroblasts) and play a role in the immune response. Mineral Cu serves to increase Vascular Endothelial Growth Factor (VEGF) that increased angiogenesis. Iron plays a role in DNA replication, Irons also acts in the formation of collagen..$^{9,11}$

Albumin is one type of protein that can enhance the proliferation of fibroblasts. Increased fibroblasts will increase the synthesis, accumulation and collagen remodeling. The more fibroblasts at the injured area, the synthesis of collagen immediately started so as to accelerate the wound healing process. Albumin also has a role in the transport of oxygen and minerals (zinc, copper, iron). Albumin is capable of stimulating transforming growth factors- $\beta 1$ (TGF- $\beta 1$ ) by macrophages. The TGF- $\beta 1$ will increase cell migration and fibroblasts proliferation at the injured area. ${ }^{12}$ The existence of fibroblasts helps to increase the production of fibronectin and collagen formation. In addition TGF- $\beta 1$ also lead to increase the formation of granulation tissue at the beginning of wound healing. ${ }^{8,13}$

Iron deficiency can cause anemia that is caused due to reduction in the blood and oxygen supplied to the injured area so that the fibroblast proliferation and angiogenesis is interrupted and resulting in the inhibition of collagen synthesis. Zinc has a key role in protein and collagen synthesis, as well as the proliferation of fibroblasts in wound healing. Zinc deficiency is associated with slow wound healing process, decreased production of skin cells and reduced strength in the wound tissue. ${ }^{14}$

The results showed that the mean of fibroblasts in the experimental group was higher than the control group. Haruan extract of $100 \%$ is the highest concentration that influence on the mean of fibroblasts than $25 \%$ and $50 \%$ concentration. This shows that the higher concentration of haruan extract, the higher its influence on the increase in the number of fibroblasts. The $100 \%$ haruan extract has a higher impact allegedly because it has more active substances on helping wound healing process than $25 \%$ and $50 \%$ haruan extract. ${ }^{15,16}$

The increase in the mean of fibroblasts in $50 \%$ haruan extract is smaller than $100 \%$ haruan extract. This is due to the addition of aquadest in $50 \%$ haruan extract, but 50\% haruan extract had higher effect than $25 \%$ haruan extract and aquadest because the active substance content in $50 \%$ haruan extract is still higher than in $25 \%$ haruan extract and aquadest.

Extract of 25\% haruan obtained the mean of fibroblasts was fewest and almost equivalent to aquadest group. This is likely due to the active substances contained in $25 \%$ haruan extract is less than $50 \%$ and $100 \%$ haruan extract. While aquadest has no active compound that can accelerate the wound healing process. Some studies suggest that normal wound healing will not occur when the et al than $2.0 \mathrm{~g} / \mathrm{dL}{ }^{16,17}$

Previous research by Sura ${ }^{11}$ proved that application of $100 \%$ haruan extract orally can help the healing process on back skin of mice. Concentration of haruan extract made after performing this study showed that the concentration of active substance is higher, in contrast to previous research where there are still more solvents. According Jannata et al. ${ }^{18}$ the higher the concentration the more active substance content in the extract.

\section{Conclusion}

The conclusion that can be drawn from this research is that haruan extract (channa striata) can increase the number of fibroblasts in the wound healing process of wistar rat's buccal mucosa with the best concentration of $100 \%$.

\section{Conflict of Interest}

The authors report no conflict of interest.

\section{References}

1. Setyaningsih W, Rachmawati N, Mandala V, et al. Reepitelisasi, kepadatan kolagen pada proses penyembuhan luka gingiva labial tikus sparague dawley setelah pemberian topikal ekstrak buah adas (foeniculum vulgare mill.) 50\%. Yogyakarta: FKG UGM; 2006.

2. Prasetyo BF, Wientarsih I, Pontjo B. Aktivitas sediaan salep ekstrak batang pohon pisang ambon (musa paradisiaca var. sapientum) dalam proses penyembuhan luka pada mencit (mus musculus albinus). Maj Obat Tradisional 2010;15: 121-137.

3. Potter, Perry. Buku ajar fundamental keperawatan konsep, proses dan praktik. Jakarta: EGC; 2005. p. 1.

4. Wahyuni ES, Utami YW, Sari WR. Pengaruh ekstrak daun sirih (piper betle linn) terhadap jumlah limfosit jaringan luka pada perawatan luka bakar derajat IIA pada tikus putih (rattus norvegicus) galur wistar. Jurnal.

5. Putri SS. Potensi daun pepaya (carica papaya L.) terhadap jumlah sel fibroblas pasca gingivektomi pada tikus wistar jantan. Surabaya: Universitas Jember; 2012.

6. Pematasari N, Pasaribu R, Razaq A. Efektivitas ekstrak ginseng asia (panax ginseng) dalam meningkatkan jumlah pembuluh darah pada soket mandibula pasca pencabutan gigi rattus norvegicus. FK UB; 2012. p. 1-2.

7. Adnyana I, Sigit J, Nurlina. Effect of administration of cork fish (channa striata) concentrate to the blood's profile of balb/c mouse thrombocytopenia model. ITB, Bandung. J Medika Planta 2012;2: 1-3.

8. Soemardini, Permaningtyas K, Chandra D. Pengaruh pemberian ekstrak ikan gabus (channa striata) terhadap kadar nitric oxide pada tikus rattus norvegicus jantan strain wistar diabetes melitus. FK Universitas Brawijaya; 2011. p. 1-3 
9. Restiana, Taslim N, Bukhari A. Pengaruh pemberian ekstrak ikan gabus terhadap kadar albumin dan status gizi penderita HIV/AIDS yang mendapatkan terapi ARV. Makassar: FK Universitas Hasanuddin; 2013. p. 1-4.

10. Santoso, Agus H. Uji potensial ekstrak ikan gabus (channa striata) sebagai hepatoprotector pada tikus yang diinduksi dengan parasetamol. Bogor: Institut Pertanian Bogor; 2009.

11. Sura GM. Efektivitas ekstrak ikan haruan (channa striata) $100 \%$ pada proses penyembuhan luka kulit punggung mencit (mus musculus) secara gambaran histopatologi. Banjarmasin: PSKG Universitas Lambung Mangkurat; 2013.

12. Febriyenti, Noor AM, Baie SBB. Physical evaluation of haruan spray for wound dressing and wound healing. 2011. p. 115-124.

13. Sunatrio S. Peran albumin pada penyakit kritis, dalam konsensus pembuatan albumin pada sirosis hati. Jakarta: FKUI Press; 2003

14. Soepriadi I. Regenerasi dan penyembuhan. Jakarta: Sagung Seto; 2013. p. 7-11.
15. Kumar V, Cotran LS, Robbins SL. Buku ajar patologi. Jakarta: EGC; 2009. p. 21, 201.

16. Pusponegoro AD. Luka. In Sjamsuhidajat R, De Jong W, editors. Buku ajar ilmu bedah. 2nd ed. Jakarta: EGC; 2005. p. 66-88.

17. Sulistiawati, Nuraini IDA. Pemberian ekstrak daun lidah buaya (aleo vera) konsentrasi $75 \%$ lebih menurunkan jumlah makrofag dari pada konsentrasi 50\% dan 25\% pada radang mukosa mulut tikus putih jantan. Denpasar: Universitas Udayana; 2011.

18. Jannata RH, Gunadi A, Ermawati E. Daya antibakteri ekstrak kulit apel manalagi (malus sylvestris mill.) terhadap pertumbuhan streptococcus mutans. E-Jurnal Pustaka Kesehatan 2014;2: 26-27.

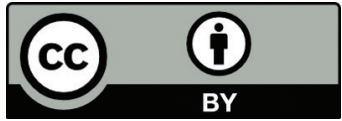

This work is licensed under a Creative Commons Attribution 